\title{
People's and Animals' Responses to Drugs
}

\author{
Xin Lou, Ming Bai and Mingsan Miao* \\ ${ }^{1}$ University of Traditional Chinese Medicine, yaolixueke, 450046 zhengzhou, China \\ * Corresponding Author
}

Keywords: Animal models; Animal experiments; Effect difference; Human diseases

\begin{abstract}
Due to the need of medical scientific research, it is necessary to study the mechanism of the occurrence and development of human diseases by making animal models, drug screening and treatment evaluation. Because of the differences between animals and people, there are differences in physiological characteristics, So that there will be a different form of expression between the pathological characteristics and the mental emotion, therefore, any animal models can not completely copy all the manifestations of human disease, it is only in one part, one side is similar to human disease. Therefore, the correctness of the animal experiment conclusion is relative. And some drugs in humans and animals on the role or degree of action are more or less the same, let us carefully think about the animal experiments. But we can't deny its application, the purpose is that we should correctly treat and apply animal experiments, we should find differences, avoid misunderstanding, uses the difference, then carry out experimental animal research to contribute to scientific research.
\end{abstract}

\section{The Application of Experimental Animals}

The experimental animal model is mainly used in the experiment physiology, pathology and experimental research for the treatment of learning (including new drug screening). With the help of the animal model of indirect research, we can consciously change those under natural conditions impossible or difficult to rule out the factors, in order to observe the results of the model more accurately and with a comparative study of human diseases, it is more convenient and effective to recognize the occurrence and development of human diseases, and to study the prevention and cure measures. The main advantages lies in these aspects: It can copy some unusual disease in clinical practice, it is comparable and helps us to fully understand the nature of the disease; Such as some radiation sickness, gas poisoning, traumatism, tumor and some hereditary disease, immunological disease, Metabolic diseases and endocrine diseases, etc., its progress is slow and the incubation period is long, It is very difficult to for more than three generations of continuous observation in the human body. Now people can choose the high incidence rate of the animal in the animal populations, then we can through appropriate means to replicate the disease model for the repeated observation of experimental conditions in human design, research and discussion, to avoid damage to human and animal experiments. We can accord the needs of researchers at any time to understand the whole process of disease samples this is difficult to do clinical and animal experiments. At the same time, Animal laboratory personnel can obtain the same conditions in a certain period of time, a large number of model material, so as to improve the comparability of results and repeatability, make the results more accurate and more in-depth. So in clinical studies in animal experiment, it is an indispensable part.

\section{Discuss the Disadvantages of Experimental Animals}

The development of human diseases is very complex, we explore the mechanism of disease with the person ourselves as the experimental object, promote the development of medicine is slow, also there are some limitations in the clinical experience in both time and space, and many experiments on the moral and method is restricted. And animal experiments tell us the feel are animals rather than human, so that many scientists thinkt animal experiment is not reliable, it is easy to lead to 
dangerous results and misleading. The animals cannot tell us the headache, numbness, loss of memory, nausea and other symptoms, more importantly, many animal species have different responses to face different drugs and substances, we can not correctly infer the human reaction according to the result. Many of the most important medical breakthroughs achieved in clinical are dependent on careful research on voluntary patients, for example the discovery of penicillin, $\mathrm{X}$ rays, and early anesthetics.

There are many problems in the clinical application of animal experiments, such as in the field of tumor, neurological and psychiatric diseases, metabolic and cardiovascular diseases, immune and infectious diseases etc., there are more or less problems in these areas. For example in cancer research, because tumor cells not only produce genetic reasons, and it closely related with the environment factors that influence the establishment of tumor animal model but also strict consideration of environmental factors, not only the tumor cells will affect normal cell proliferation, also in the comprehensive conditions of the mutation, which brings a big problem to study. For these uncontrollable factors we need to avoid in the animal experiment; Parkinson Alzheimer's disease animal model established by rodents, it is mainly used for drug evaluation and research. Although rodents are small, easy to operate, cheap and other advantagesand so on, but there is a big difference in anatomy, metabolism and physiologyand so on, it requires us to correctly understand the difference and make better use of it.

\section{Differences between People, Animals, Responses to Drugs}

People and animals exist in such aspects as species, the structure are different, and also there are some differences between the pathological features and the mental emotion, for example, people and dogs are very different in physiological structure, especially the brain structure, the regulating function of the brain, and the number of hepatic enzyme species difference is big. These determine the pharmacological and toxicological effects of drugs in humans and animals, rather the opposite, such as the graceful jessamine herb is a highly toxic to people, but it for the pig it is exhibited.

The responses of different drugs or compounds in different species of animals are very different, and also it is difference in some dosage of drug dosage of people and animals. For example, Croton, people eat it can cause severe diarrhea, this is as everyone knows, but also at the same time it known as the Croton fertilizer, the mice eat it not only will not cause diarrhea, it increase weight, for mouse it is a kind of fertility. Such as thyroid hormone drugs, dosage is very different of man and animals; Such as estrogen can terminate early pregnancy in rats and mice, but it can not the termination pregnancy of person; The main effect of morphine on dogs, rabbits, monkeys and humans is central inhibition, while it for the mice and cats is central excited; Aniline and its derivatives for dogs, cats, guinea pigs and people produce similar pathological changes in degeneration of hemoglobin field, the rabbit is not likely to happen, in mice, rats and other rodents are not happen this phenomenon. Not only western medicine there are many of these drugs, in terms of traditional Chinese medicinethere is also the existence of such drugs; So we can not blindly use the results of experimental animals in the human body, it must haver a long period of clinical practice it can be applied to the clinical; 


\begin{tabular}{|c|c|c|}
\hline Drug & Response to human & Response to animal \\
\hline Croton & $\begin{array}{l}\text { People take } 20 \text { drops of croton oil } \\
\text { can be lethal. Contact crotonic } \\
\text { cause acute dermatitis and systemic } \\
\text { symptoms; After pregnant women } \\
\text { eat can cause abortion }\end{array}$ & $\begin{array}{l}\text { To crotonic liquid feed mice, rabbits, } \\
\text { goats, duck, goose, no response; } \\
\text { Cattle, horses food cause symptoms } \\
\text { such as diarrhea, loss of appetite, the } \\
\text { person that weigh death }\end{array}$ \\
\hline $\begin{array}{l}\text { Triptery } \\
\text { gium } \\
\text { wilfordi } \\
\text { i }\end{array}$ & $\begin{array}{l}\text { It is toxic to humans, dogs, pigs, } \\
\text { and insects }\end{array}$ & The rat, rabbit, sheep non-toxic \\
\hline $\begin{array}{l}\text { Hook } \\
\text { kiss } \\
\text { (gracefu } \\
1 \\
\text { jessami } \\
\text { ne herb) }\end{array}$ & $\begin{array}{l}\text { Plants are highly toxic, roots, } \\
\text { leaves especially poison; Treatment } \\
\text { can be used for indigestion, } \\
\text { diarrhea, insect code, etc }\end{array}$ & $\begin{array}{l}\text { Pigs, sheep food laid not only } \\
\text { non-toxic, but also make its thus } \\
\text { sleek, weight gain and the blast effect }\end{array}$ \\
\hline nutmeg & $\begin{array}{l}\text { Can treat deficient cold flow field, } \\
\text { often such as abdominal pain, } \\
\text { vomiting, external use can make } \\
\text { parasites expellent, treat rheumatic } \\
\text { pain, etc., can also be as a } \\
\text { condiment, industrial oil, raw } \\
\text { materials, etc }\end{array}$ & $\begin{array}{l}\text { The dog ate the nutmeg can cause } \\
\text { convulsions, heart attack and death }\end{array}$ \\
\hline & $\begin{array}{l}\text { Treatment of kaschin-beck disease, } \\
\text { keshan disease } \\
\text { Lily disease; Chinese medicine } \\
\text { commonly used formula to treat }\end{array}$ & $\begin{array}{l}\text { Can be added inorganic salt, but may } \\
\text { cause heavy metal poisoning } \\
\text { Cats eat to any part of lily can lead to } \\
\text { acute renal failure. }\end{array}$ \\
\hline
\end{tabular}

Bulb of the infusion of guinea pig, rabbit, and the cat's uterus has very strong excitation, can make the pigeon vomiting; Cattle and sheep eat bulbs, immediately appear convulsion, dilated pupils, plummet, etc.; Cats eat bulb can cause diarrhea, fever, serious will be death;

Corn Have a cough, pain, stop leakage, The cat after eating a lot of the stem poppy the role of hypnosis. Seeds can be leaf manic, uneven breath

Onions Can be used to treat diabetes, obesity, indigestion, hypertension, hyperlipidemia, atherosclerosis, cold sweat, nasal congestion, dyspepsia, stay, etc.; As a health food, prevent cancer, prevent aging, prevent colds, help digestion, help clear the blood, improve constipation, prevent osteoporosis, raise colour, whitening, sterilization, fall blood pressure, etc.;

acacia Eat raw leaves and fruit can cause nausea and diarrhea

Cats, dogs eat onion in 1 to 2 days, serious is hemolyze deep red urine, illness aggravating gradually, normal or lower body temperature, severe poisoning can cause death.

Animals such as sheep, rabbit ate is ok

Castor 10 grain can be lethal adults eating

bean castor beans, raw children $3 \sim 5$ grain of castor beans can be fatal

A grain of castor beans can keep the cats on the poisoning 


\begin{tabular}{|c|c|c|}
\hline Drug & $\begin{array}{l}\text { Response to } \\
\text { human }\end{array}$ & Response to animal \\
\hline $\begin{array}{l}\text { Caffeine class } \\
\text { of drugs }\end{array}$ & $\begin{array}{l}\text { Excited the brain } \\
\text { cortex and } \\
\text { analgesia }\end{array}$ & $\begin{array}{l}\text { Medulla oblongata spinal cord caused } \\
\text { excitement, convulsions convulsions coma or } \\
\text { death in the end }\end{array}$ \\
\hline $\begin{array}{l}\text { Non-steroidal } \\
\text { anti-inflammato } \\
\text { ry drug }\end{array}$ & $\begin{array}{l}\text { safe for human } \\
\text { beings }\end{array}$ & $\begin{array}{l}\text { Lead to pets (dogs, cats, birds and other small } \\
\text { animals such as mink, gerbils) serious } \\
\text { problems, kidney failure and peptic ulcer is } \\
\text { the most common problems }\end{array}$ \\
\hline antidepressants & $\begin{array}{l}\text { Mainly used to } \\
\text { treat depression as } \\
\text { the outstanding } \\
\text { symptoms of } \\
\text { mental illness of } \\
\text { psychotropic drugs }\end{array}$ & $\begin{array}{l}\text { Excessive take these drugs to animals can } \\
\text { lead to serious neurological problems, such } \\
\text { as sedation, ataxia, tremor, epilepsy. Some } \\
\text { antidepressants may also cause serious heart } \\
\text { rate, blood pressure and body temperature to } \\
\text { rise. Can cause severe poisoning. }\end{array}$ \\
\hline $\begin{array}{l}\text { Drugs } \\
\text { containing } \\
\text { pseudoephedrin } \\
\text { e }\end{array}$ & $\begin{array}{l}\text { The commonly } \\
\text { used antipyretic } \\
\text { analgesic drugs, } \\
\text { relieve congestion } \\
\text { and runny nose }\end{array}$ & $\begin{array}{l}\text { Pseudoephedrine for dogs and cats have a } \\
\text { very low degree of safety, often abnormal; } 30 \\
\text { minutes after eating }\end{array}$ \\
\hline $\begin{array}{l}\text { Drugs } \\
\text { containing } \\
\text { acetaminophen }\end{array}$ & $\begin{array}{l}\text { Antipyretic } \\
\text { analgesic drugs }\end{array}$ & $\begin{array}{l}\text { Acetaminophen can cause liver failure and } \\
\text { red blood cell damage, especially for the cat, } \\
\text { as long as a little bit, is likely to be fatal; }\end{array}$ \\
\hline $\begin{array}{l}\text { Diazepam and } \\
\text { antipsychotic } \\
\text { drugs }\end{array}$ & $\begin{array}{l}\text { Used to reduce } \\
\text { tension, make } \\
\text { human sleep better }\end{array}$ & $\begin{array}{l}\text { About half of the dog after consumption } \\
\text { become excited, but no drowsiness } \\
\text { phenomenon. Some can lead to serious } \\
\text { animal sleepiness, ataxia (drunk), slow } \\
\text { breathing. For some cat antipsychotic drugs } \\
\text { can lead to liver failure. }\end{array}$ \\
\hline $\begin{array}{l}\text { Adhd drugs } \\
\text { treatment }\end{array}$ & $\begin{array}{l}\text { Mainly used for } \\
\text { the treatment of } \\
\text { attention deficit or } \\
\text { attention deficit } \\
\text { disorder }\end{array}$ & $\begin{array}{l}\text { Animals even very small amounts of intake } \\
\text { of these drugs can also lead to lifelong threats } \\
\text { such as epilepsy, tremor, increased body } \\
\text { temperature, heart disease and other } \\
\text { problems. }\end{array}$ \\
\hline Beta blockers & $\begin{array}{l}\text { Drugs used to treat } \\
\text { high blood } \\
\text { pressure, applied } \\
\text { widely in the } \\
\text { crowd }\end{array}$ & $\begin{array}{l}\text { For animals less doses can cause serious } \\
\text { problems. Too much can have dangerous life, } \\
\text { resulting in decreased blood pressure and } \\
\text { slow heart rate. }\end{array}$ \\
\hline $\begin{array}{l}\text { Thyroid } \\
\text { hormone }\end{array}$ & $\begin{array}{l}\text { Treatment within a } \\
\text { quantity without } \\
\text { any adverse } \\
\text { reaction }\end{array}$ & $\begin{array}{l}\text { Animal consumption is much higher than } \\
\text { human, usually eat this drug will not cause } \\
\text { too much of an issue, but a short time } \\
\text { excessive intake can lead to muscle tremor, } \\
\text { neurotic, breath, and heart rate super fast and } \\
\text { aggressive. }\end{array}$ \\
\hline $\begin{array}{l}\text { Antibiotic } \\
\text { medicines }\end{array}$ & $\begin{array}{l}\text { Treatment of all } \\
\text { kinds of bacteria } \\
\text { infection or } \\
\text { inhibition of } \\
\text { infection }\end{array}$ & $\begin{array}{l}\text { can accelerate the growth of animals; } \\
\text { Plant-eating livestock easy cause digestive } \\
\text { functional disturbance, therefore herbivorous } \\
\text { poultry ban oral antibiotic drugs; }\end{array}$ \\
\hline Estrogen drugs & $\begin{array}{l}\text { Can't terminate } \\
\text { pregnancy }\end{array}$ & Termination of early pregnancy rats and mice \\
\hline $\begin{array}{l}\text { Fluoroquinolone } \\
\text { drugs }\end{array}$ & $\begin{array}{l}\text { Affect the } \\
\text { development of } \\
\text { cartilage, causes } \\
\text { the joint pain, } \\
\text { children grow } \\
\text { slower. Taboo } \\
\text { drugs belong to } \\
\text { children }\end{array}$ & $\begin{array}{l}\text { No special requirements to animal } \\
\text { medication }\end{array}$ \\
\hline
\end{tabular}




\section{Discussion}

The Differences between Different Experimental Animals. For example, for the sensitivity of adrenal cortical hormone, C57BL mice were 12 times higher than DBA mice; But for the sound stimulation of DBA mice to stimulate the sensitive hearing can appear clonic convulsion special, serious or even death, and C57BL mice didn't appear this kind of phenomenon; the reaction to the Newcastle virus, DBA mice cause encephalitis, $\mathrm{C} 3 \mathrm{H}$ mice cause pneumonia; For the study of tumor experiment, different species of mice have different morbidity, the incidence of C57BL mice virous tumor rates were low, but the female reproductive a mice $80 \%$ were breast cancer, tianjin white 1 series for low incidence of tumor in mice and the department of tianjin white 2 for the tumor incidence rate is high. The sensitivity of experimental animal of Sendai virus, DBA mice is 100 times than C57BL mice. In our experiments, experimental materials are more suitable for the course of the experiment and the development of the follow-up, provide new ideas and methods for the study of the better clinical drugs and treatment methods.

For example in the drugs on the liver toxicity research findings, Dempsey ROMI due to high concentration in plasma drug dogs, and then lead to toxicity to the liver, but the research in rats and monkeys did not produce obvious liver toxicity. Study on transdermal absorption of drugs, the animal species in differences in morphology of skin is large, so even the same drug may produce different effects.

\section{Differences between Animals and People}

Among all the animals in nature, in addition to the vertical human animal, for most of the rest of the reptile animal amphitropous. From the perspective of traditional Chinese medicine theory, the longitudinal vertical diameter for the day, so as to weft, vertical through heaven and earth, the transverse Chahar gas. So the human intrinsic weather most, advanced brain, animal is dominated by gas, the mind is less developed, it also shows that human and animal there is a great difference. Animal experiments in the study of Chinese medicine can replace the human body to predict the toxic side effects of traditional Chinese medicine, we can avoid the harm caused by the experiment in the human body. And the toxic side effects of traditional Chinese Medicine records are not uncommon, such as:< Huainan Zi Xiu > records:" Shennong taste various medicinal materials, sweet and bitter of the water, people know what to lay out, at this time, in a single day meet more than 70 kinds of toxic Chinese herbal medicines", we should proper use the animal experiments, it can bring a lot of convenience for the clinical application of traditional Chinese medicine; At the same time, there are also objective differences in physiology, such as rats without gallbladder, and with the physiological structure of human beings is also different. he Trabbit heart test, because the structure of rabbit with different human chest, not break the longitudinal diaphragm without artificial respiration, and the physiological state of human body is not the same;

\section{Experimental Study on the Difference}

In medical research, animal models, animal experiments are serve for people, the results of animal experiments and animal experiments are extrapolated to humans, which is the extrapolation of animal experiments. Because the animal and human after all is not the same species, such as rats, born without gallbladder, gallbladder function cannot do research, if you want to do it, it is to do common bile duct bile was collected in order to study the digestive function; such as both dogs and rabbits can be used as the experimental animal, the dog's parathyroid gland is located on the surface of the two thyroid glands, it has fixed position.t The parathyroid glands of rabbits were more dispersed ,the location is not fixed, so it is more appropriate to choose a dog for parathyroid removal. For example, there are obvious differences between the human and several common experimental animals in microbial population, The dominant group of human reproductive tract is Lactobacillus, the dog is similar to human reproductive tract flora, Lactobacillus percentage is second only to the human body, therefore, it is more suitable for the study of a series of diseases 
related to Lactobacillus, rhesus monkey In group P. Copri, therefore it is suitable for study about P. Copri diseases related to vaginal infection. such as frogs and toads, the brain is not developed, can not be used for the study of higher nervous activity, but the right to do a simple experiment. The cat is the host of Toxoplasma gondii and it is a good material for the study of Toxoplasma gondii.

For the above mentioned situation, the animal experiments on medical research cannot be regarded as Sovereign, we should objectively use it, after all, animals are not human, the success of animal model can not avoid the existence of accidental factors, So we should have a rational attitude towards animal models. From the above discussion we can see that there are advantages of animal experiments but also it have many problems to be solved, but for our study of human diseases and it has made a great contribution. We need to find more problems, find difference, make good use of these differences, to provide high quality research materials for scientific research, to provide better help for medical research.

\section{Acknowledgements}

1MiaoMingsan, man, Professor, ph. D., mainly engaged in Traditional Chinese Medicine pharmacology teaching and research.0371-65962546, E-mail: miaomingsan@163.com. project team of outstanding scientific and technological innovation in Henan province (TCJ2014-391), the natural science foundation of Henan province (132300410019), science and technology innovation team of Zhengzhou city (131PCXTD612)

\section{Reference}

[1] Xu Lin, Zhang Yun, Liang Bin, Lv Longbao, Chen Ceshi, Chen Yongbin, Zhou Jumin, Yao Yonggang. Study on experimental animal in tree shrews and human disease research overview of tree shrew animal models of [J]., 2013,02:59-69.

[2] Bi Jinlian, Zhang Xiuqin, Yu Cheng Yang, Zou Weihong. The animal model of pharmacology of traditional Chinese medicine research progress of [J]. China pharmacy, 2015, 34:4877-4879.

[3] Xue Lixiang, Zhang Fengzhu, Sun Ruijuan, Dong He. Animal model diseases in China present situation and Prospect of [J]. China Science: Life Sciences, 2014, 09:851-861.

[4] Wan Jiying, Han Wei. Development and application of tumor experimental animal model [J]. medical review, 2009,19:2959-2961.

[5] Xu Lin. Animal model of human disease [J]. zoological research, 2011,01:1-3.

[6] Dong Xianhui, Chai Xiqing. Transgenic animal models of Alzheimer's disease: how close to the pathological characteristics of [J]. China tissue engineering research, 2013, 46:8075-8082.

[7] Tian Ting, Ma Xianghua, Shen Jie. Overview of animal model of type 2 diabetes [J]. review of medicine, 2011,06:905-908.

[8] The research progress of animal model of nonalcoholic fatty liver disease [J]. Chinese Journal of experimental formulae, (2013, 02:357-360.)

[9] Cui Yifan, Wang Qingguo. Study on the significance and modeling method of traditional Chinese medicine combined with syndrome model in traditional Chinese medicine [J]. Tianjin traditional Chinese medicine, 2009,06:446-448.

[10] Li Xiaojuan, Bai Xiaohui, Chen Jiaxu, and so on,, and so on, and so on,, and so on, and so on. The research methods and Prospect of the animal model of Chinese medicine [J]., Chinese Journal of traditional Chinese medicine,,,,, 2014,07:2263-2266.

[11] euge, Sun Zhaolin, Ji Yubin, Chen Mingcang. The animal model of diabetes in species and study of [J]. Chinese pharmaceutical, 2012,09:1-4. 
[12] Qian Jun, Sun Yucheng. Laboratory animal and biosafety [J]. Chinese Journal of comparative medicine, 2011, Z1:15-19+12.

[13]Zhu Jinghe, Zhao Jinming, Qin Wenyan, Song Dafu, Bao Yulong, Liu He, fan Yinglan. Experimental hyperlipidemia animal model [J]. overview of laboratory animal science, 2012,02:48-52.

[14] Gu Dongshu. Intestinal, human and animal experimental oral, genital tract microbial groups [D]. Southern Medical University, 2016

[15] Li Wei. Comparative study on the diversity of main bacteria in several common laboratory animals and human intestinal tract [D]. Southwestern University, 2011 